
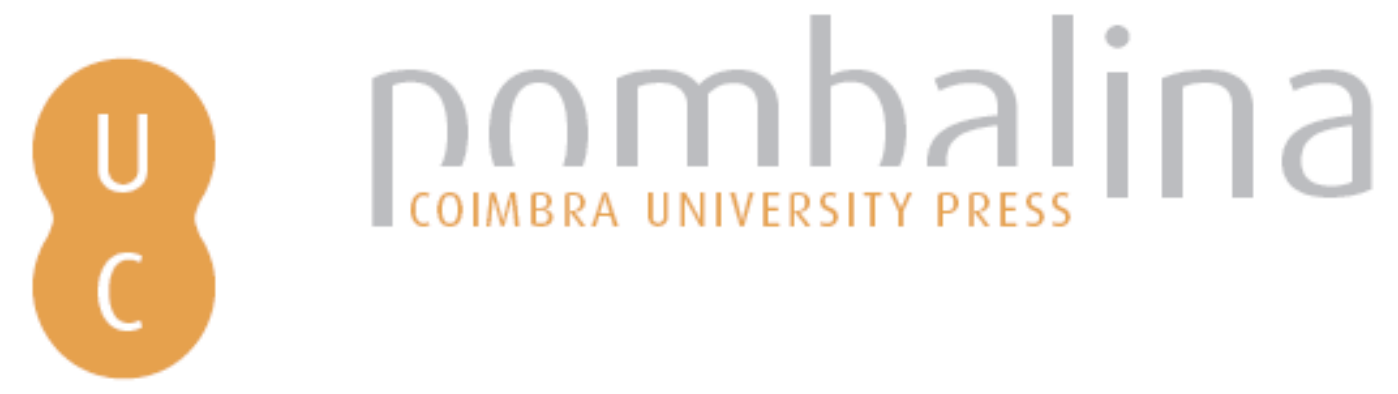

\title{
Interruption: preposterous reading of Maria Irene Ramalho de Sousa Santos
}

\author{
Autor(es): $\quad$ Statkiewicz, Max
}

Publicado por: Imprensa da Universidade de Coimbra

URL

persistente: URI:http://hdl.handle.net/10316.2/42334

DOI: DOI:https://doi.org./10.14195/978-989-26-1308-6_24

Accessed : $\quad$ 26-Apr-2023 13:29:25

A navegação consulta e descarregamento dos títulos inseridos nas Bibliotecas Digitais UC Digitalis, UC Pombalina e UC Impactum, pressupõem a aceitação plena e sem reservas dos Termos e Condições de Uso destas Bibliotecas Digitais, disponíveis em https://digitalis.uc.pt/pt-pt/termos.

Conforme exposto nos referidos Termos e Condições de Uso, o descarregamento de títulos de acesso restrito requer uma licença válida de autorização devendo o utilizador aceder ao(s) documento(s) a partir de um endereço de IP da instituição detentora da supramencionada licença.

Ao utilizador é apenas permitido o descarregamento para uso pessoal, pelo que o emprego do(s) título(s) descarregado(s) para outro fim, designadamente comercial, carece de autorização do respetivo autor ou editor da obra.

Na medida em que todas as obras da UC Digitalis se encontram protegidas pelo Código do Direito de Autor e Direitos Conexos e demais legislação aplicável, toda a cópia, parcial ou total, deste documento, nos casos em que é legalmente admitida, deverá conter ou fazer-se acompanhar por este aviso.

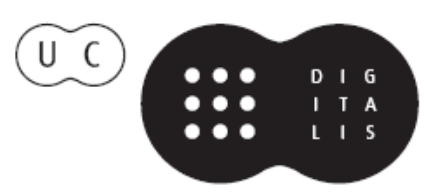





\section{NTERRUPTION: PREPOSTEROUS READING OF MARIA IRENE RAMALHO DE SOUSA SANTOS}

Max Statkiewicz

Resumo: O conceito de "interrupção" de Maria Irene Ramalho Santos tem como objetivo determinar a relação entre a literatura e o mundo. A singularidade da sua perspetiva reside no facto de questionar de forma radical a visão aristotélica tradicional, recusando-se a efetuar uma separação entre a literatura e a história. A interrupção funde o artístico e o político/ histórico, ambos radicados na linguagem: "o que não pode ser dito é uma não-coisa". A poesia é "fala pura", mas as coisas também são "ditas" no diálogo entre a poesia e o pensamento. A um tempo continuando e interrompendo a tradição interruptiva do entretien infini de Maurice Blanchot, Maria Irene Ramalho Santos exalta a poesia no seu diálogo "pre-póstero" com Coleridge, Pessoa (e os seus vários heterónimos), Rich, saíz e muitos outros, conferindo uma excecional dignidade à atividade da crítica literária.

Palavras-chave: interrupção; pre-póstero; Pessoa; saíz; diálogo; poesia; pensamento. 
Abstract: Maria Irene Ramalho Santos' "interruption" attempts to determine the relationship between literature and the world. The distinctiveness of her view consists in the fact that it radically questions the traditional Aristotelian view, and refuses to separate literature and history. "Interruption" brings together artistic and political/historical considerations, which are rooted in language: "if things cannot be said, they are no-things." The things are "purely spoken" in poetry, but they are also "said" in the dialogue between poetry and thought. Continuing, and interrupting, the interruptive tradition of Maurice Blanchot's entretien infini, Maria Irene Ramalho Santos exalts poetry in her "pre-posterous" dialogue with Coleridge, Pessoa (with his heteronyms), Rich, saíz, and with many others, bestowing at the same time an exceptional dignity upon the work of criticism.

Keywords: interruption; pre-posterous; Pessoa; saíz; dialogue; poetry; thought.

Aristotle's famous claim that poetry does not register the events

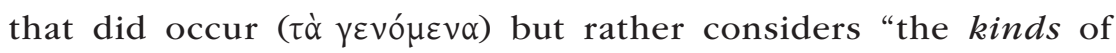
things that might occur and are possible in terms of probability or

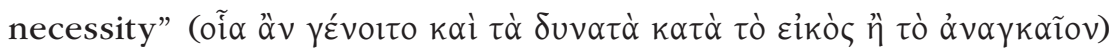
was largely accepted for a long time as a valid distinction between literature and history (1451b 5-6). ${ }^{1}$ To be sure, Aristotle's iotopía is not exactly the modern, say Ranke's, Geschichte, and his roínors is not exactly poetry in the modern sense, but the rapprochement

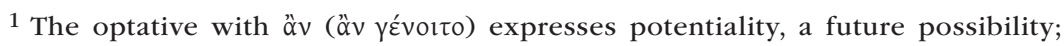
see Herbert, 407f. 
between the two is perhaps not illegitimate, and certainly legitimate is the problematization of the relationship between the fictional world of a poetic work and the world of the writer and the reader; and it is legitimate to ask what Aristotle "could have thought" about this relationship.

The world of the writer, the reader, and the work does not need to be one and the same world, of course, but still there needs to be some common experience if the work of fiction is to be relevant. The ancient Greek word for this commonality of experience was $\mu$ í $\mu$ or imitation, possibly "representation" (as some - perhaps influenced

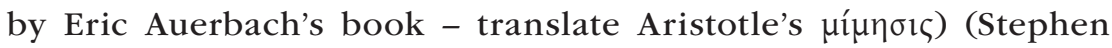
Halliwell, The Poetics of Aristotle 37). Other modern words for this relationship would be "aestheticization" (Oscar Wilde), Verklärung or "transfiguration" (Friedrich Nietzsche), "defamiliarization" (Viktor Shklovsky's остранение, Bertolt Brecht's Verfremdung), "clarification” (Leon Golden), "prefiguration, configuration, and refiguration" (Paul Ricœur), etc. Irene Ramalho Santos' "interruption" belongs to these attempts to determine the relationship between literature and the world. The distinctiveness of her view consists in the fact that it radically questions the traditional Aristotelian view, and refuses to separate literature and history. Indeed, and perhaps paradoxically, interruption is what brings together the artistic and political/ historical considerations. Ramalho Santos calls the "unreal reality" that interrupts poetic inspiration in the idealist sense of the romantic tradition, "politics": to be sure, not in the sense of the politicians' politics, but rather in the Aristotelian sense of the communal determination of the human being, or in the Heideggerian sense of being-in-the-world as the most proper characteristic of human Dasein.

Anankē or political necessity, writes Ramalho Santos, re-interpreting

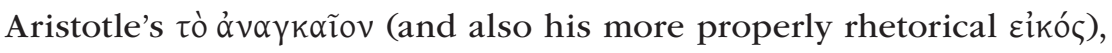
"by bringing the political to break in upon the poet's unifying 
imagination", in fact "accounts for the poetical" (222). Thus the

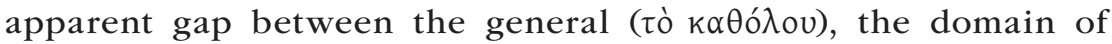
philosophy and, by extension, poetry, on the one hand, and the

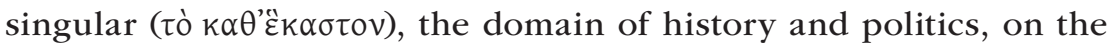
other hand, is shown to be just that: apparent (Aristotle 1451b9-10). ${ }^{2}$ Language itself is both general and singular in its poietic nature. It resides both in the verisimilitude of the general and in the necessity of the singular; no region of being can escape the régime of language: "when words break of / no thing may be," says Stephan George; and Ramalho Santos: "if things cannot be said, they are no-things" (230; cf Heidegger "The Nature of Language" 60-61; "Das Wesen der Sprache" 163). And the naming of things does not depend, not entirely, on the poet. Poet himself/herself has to be named; and this naming is not obvious in the epoch of depersonalization (Entpersönlichung) (cf. Friedrich 36ff.; de Man 171f). Fernando Pessoa's heteronyms: Alberto Caeiro, Ricardo Reis, Álvaro de Campos, and others - as well as the "orthonymic Pessoa" - problematize the naming of the subject of the poem; their "mental origin" lies in Pessoa's "persistent and organic tendency ... to depersonalization and simulation," as he himself affirms in one of those statements that may refer to both the ethical and the theatrical sense of his proper name (Pessoa 7). Ramalho Santos shows how some of the heteronyms are further differentiated according to the state of health or sickness (which is, she says, "the rudest form of self-interruption"), and she calls this elaborated world of personae "the most daring dramatization of interruption as a poetic strategy" and "the most accomplished decentering or even suspension of the subject in modernist poetry," even though, or perhaps all the more because Alberto Caeiro's self-

${ }^{2}$ Here lies the main difference between the Aristotelian and the Heideggerian conception of experience and truth; for Lacoue-Labarthe, the poetic experience is quintessentially singular (Poetry As Experience 47/71 et passim; La poésie comme expérience 69). 
-interruptive disease attempts to question the very notion of poetic depersonalization and disengagement (Ramalho Santos 237-238).

Maurice Blanchot had already used the notion of l'interruption in order to question the traditional interpretation of Aristotle's roínбı, but he also focused on the poietic nature of human intercourse as such in the form of infinite conversation, l'entretien infini (The Infinite Conversation 75ff; L'entretien infini 106ff). Only such an interruptive dialogue can protect against all "terrible monologues." A dialogue between poets or between poetry and thought is privileged precisely because of its poietic, and at the same time interruptive nature. Ramalho Santos' staging of a dialogue between poets can be inscribed in this project of a "dialogue between poetry and thought", which Heidegger proclaimed to be the task of thinking and of poetry, of the thinking of poetry (On the Way to Language 161; Unterwegs zur Sprache 38f). Far from dispersing the power of language, such communal interruptive exchange intensifies it. Referring to António Ramos Rosa's notion of poetry as "the intact", and to Adrienne Rich's notion of poetry as "a concentration of the power of language", Ramalho Santos affirms that "the poetical needs the interruption of the political fully to ground itself as holding the power of language intact" (223). The power of language does not consist in the artistic or theoretical mastery, but rather in its interruptive dialogue: not a masterful, rhetorical discourse, but a conversation with its wording, silencing, waiting, rewording; in Paul Celan's and Büchner's memorable image, not the exalted speeches of Camille, Danton, Fabre, and the others about art (Von der Kunst ist gut redden), ${ }^{3}$ but Lucile's sensuous and political word-act-step: "Es lebe der König" (Celan "Der Meridian": 189; "Meridian": 40). ${ }^{4}$

\footnotetext{
3 "It feels good to talk about art," Celan, Selected Poems 402.

${ }^{4}$ Celan, Collected Prose 40: "Long live the king!".
} 
Although less dramatic than Celan's and Lucile's "counter-word" (Gegenwort), Ramalho Santos' and Hanni Ossot's "husband, cat, and kitchen" perform a similar interruptive function; if they are less spectacular, less obviously political, it is precisely because Ramalho Santos intends to include the every-day, the domestic (the "feminine") sphere into the realm of the political; in this way, the interruption is all the more striking. For what both Lucile and Hanni Ossot interrupt is not so much art as technique, as device (Skhlovsky's прием), but Art - ab Kunst, Celan says - a romantic idea of inspiration, of genius, a belief in an exceptional nature of the poetic utterance. However, poetry is not a privileged kind of language, writes Ramalho Santos, not in the sense of being invulnerable to the dangers of the every-day flattening, to the "apparently smooth course of conventionally spoken life," to the interruptive intrusion of a "person on business from Porlock," famously breaking up Coleridge's vision of the palace of Kubla Khan. This, however, becomes apparent only through interruption, be it in the form of a gnawing worm, as in Alberto Pimenta's exemplary case. Pimenta's "cuneiform song (before and after the worm)" [canção cuneiforme (antes e depois de Ihe dar o bicho)] is indeed an excellent illustration of a preposterous, before-and-after mode of interruption (232f).

prospero saíz's magnificent long poem the bird of nothing epitomizes for Ramalho Santos the poetic mode of interruption on an epic scale. Its first line, CaeSurA, could function as its interpretive subtitle; the bird of nothing interrupts both the "idea of poetry as an absolute" (in the tradition of Shelley) and the "idea of the poem as the nation" (in the tradition of Whitman). It is "the epic of American consciousness made problematic" (247). the bird of nothing is also an interruption of the Aristotelian distinction between the general ( $\tau$ ò

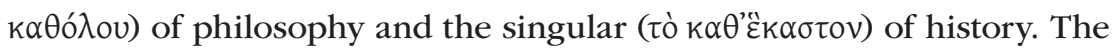
"bird" of the poem disperses into so many kinds of the common and less common, mythical, poetic, domestic and seemingly foreign, kinds 
of birds; there are still "kinds", but their generic unity is "nullified". As the French oiseau, as Derrida's animot, saíz's "bird" should sound just like the plural (oiseaux, animaux) sounds. The same process of interrupted generality marks the long list of "american" rivers:
[and arizona a little papago spring
and connecticut a mohegan long river
and the ottawa's big lake michigan
and mnisota the dakota's cloudy water
and the big river mississippi of the illinois
and the missouri for those of the dugout canoe
and the mighty flat river nibdhathka of the omaha
and allegheny-ohio the beautiful river of the seneca
and the tanasi little river of the cherokee
and the algonquian river name wisconsin
and the big river-flats wyoming of the delaware] $(148)^{5}$

Of course, the list is "long" only to those impatient to arrive at a poetic/philosophical logos, not to those who, like Santos and Lacoue-Labarthe, believe in the essential singularity of poetry. saíz's "and" (here and elsewhere in the poem) is not exactly a comma, certainly not a mark of continuity, but precisely the mark of interruption; repeated at the beginning of each line, "and" is paratactic par excellence, resisting the Aristotelian muthos or logos, with its beginning, middle, and end - interruptive of the conventional naming, classifying, registering. Paradoxically perhaps, saíz's poetry and Ramalho Santos' interruptive/dialogical reading suggest a rereading of the poetic tradition, including the Homeric parataxes as a "preposterous" interruption of the Aristotelian tradition in the critical thought ("The poem may stand only insofar as it shuns poetics", writes saíz in his

5 Quoted in Atlantic Poets 247. 
poetic preface $[v])$. Poetic "singular plurality" appears all the more striking when set against ("interrupting") this tradition. Extolling the poetic tradition, Ramalho Santos' interruptive dialogue bestows at the same time an exceptional dignity upon the work of criticism.

\section{Works cited}

Aristotle. Poetics. Trans. Stephen Halliwell. Cambridge: Harvard University Press, 1995. Print.

Auerbach, Eric. Mimesis: The Representation of Reality in Western Literature.1953. Trans. Willard R. Trask. Princeton: Princeton University Press, 2003. Print.

Blanchot, Maurice. The Infinite Conversation. Trans. Susan Hanson. Minneapolis: University of Minnesota Press, 1993; L'entretien infini. Paris: Gallimard, 1969. Print.

Celan, Paul. "Der Meridian.” Gesammelte Werke. Vol. 3. Frankfurt am Main: Suhrkamp, 1983; "Meridian." Collected Prose. Trans. Rosmarie Waldrop. New York: The Sheep Meadow Press, 1986. Print.

Celan, Paul. Selected Poems and Prose of Paul Celan. Trans. John Felstiner. New York: W. W. Norton, 2001. Print.

de Man, Paul. Blindness and Insight. Minneapolis: University of Minnesota Press, 1971. Print.

Friedrich, Hugo. Die Struktur der Modernen Lyrik. Hamburg: 1967. Print.

Halliwell, Stephen. The Poetics of Aristotle: Translation and Commentary. Chapel Hill: The University of North Carolina Press, 1987. Print.

Heidegger, Martin. "The Nature of Language." On The Way to Language, 55-108; "Das Wesen der Sprache." Unterwegs zur Sprache, 157- 216. Print.

Heidegger, Martin. On the Way to Language. Trans. Peter D. Hertz. San Francisco: HarperCollins Publishers, 1982; Unterwegs zur Sprache. Pfullingen: Neske, 1959. Print.

Herbert, Weir Smyth. Greek Grammar. Cambridge: Harvard University Press, 1956. Print.

Lacoue-Labarthe, Philippe. Poetry As Experience. Trans. Andrea Tarnowski. Stanford: Stanford University Press, 1999; La poésie comme expérience. Paris: Christian Bourgois, 1986. Print.

Pessoa, Fernando. Always Astonished: Selected Prose. Ed. Edwin Honig. San Francisco: City Lights Books, 1988. Print.

Ramalho Santos, Irene. Atlantic Poets: Fernando Pessoa's Turn in Anglo-American Modernism. Hanover and London: University Press of New England, 2003. Print.

Saíz, Próspero. The Bird of Nothing \& Other Poems. Madison, WI: Ghost Pony Press, 1993. Print. 